\title{
ОРІЄНТАЦІЯ КЕРІВНИКА УНІВЕРСИТЕТУ НА РЕЗУЛЬТАТИВНИЙ РОЗВИТОК ЗАКЛАДУ
}

\section{Пропозиції Інституту вищої освіти НАПН України щодо цільових показників діяльності закладу вищої освіти, які включаються до контракту з керівником} https://doi.org/10.37472/2707-305X-2020-2-2-11-7
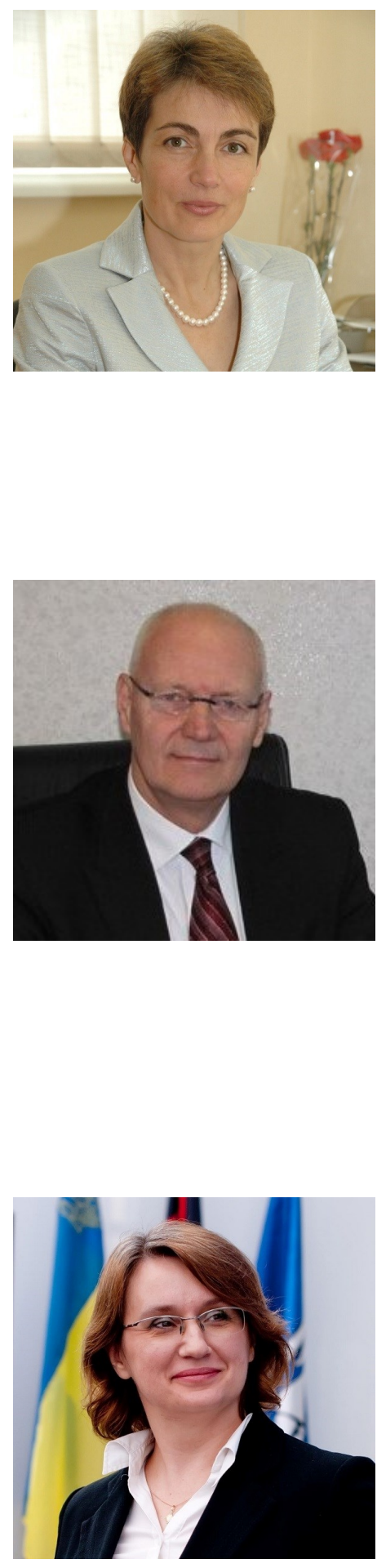

ДРАЧ Ірина Іванівна

доктор педагогічних наук, дочент, перший заступник директора Інституту вищої освіти Національної академії педагогічних наук України, м. Київ, Україна (iD) 2

КАЛАШНІКОВА Світлана Андріївна доктор педагогічних наук, профессор, член-кореспондент НАПН України, директор Інституту вищої освіти Національної академії педагогічних наук України, член Національної команди експертів з ресоормування вищої освіти, м. Київ, Україна

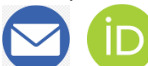

\section{лУГОВИЙ Володимир Іларіонович}

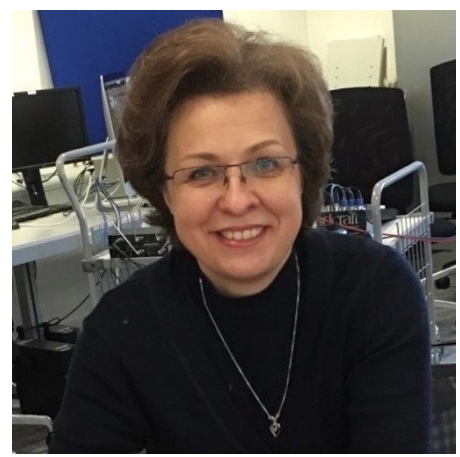
доктор педагогічних наук, профресор, дійсний член (академік) НАПН України, перший віцепрезидент Начіональної академії педагогічних наук України, член Національної команди експертів з ресрормування вищої освіти, м. Київ, Україна

\section{(iD) $\triangle$}

\section{СЛЮСАРЕНКО ОЛЕНа Миколаївна} доктор педагогічних наук, старший науковий співробітник, заступник директора з наукової роботи Інституту вищої освіти Національної академії педагогічних наук України, м. Київ, Україна

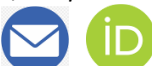

\section{ТАЛАНОВА Жанна Василівна}

доктор педагогічних наук, старший науковий

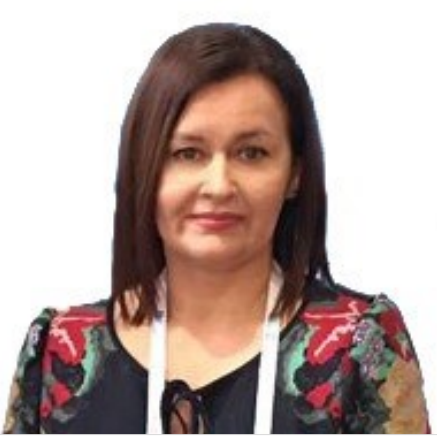
співробітник, доцент, головний науковий співробітник відділу політики і врядування у вищій освіті Інституту вищої освіти Начіональної академії педагогічних наук України, менеджер з аналітичної роботи Начіонального Еразмус+ офрісу в Україні, м. Київ, Україна 
Анотація. Підвищення ефективності діяльності закладів вищої освіти - одне із ключових завдань на порядку денному реформи вищої освіти України. Для його виконання має бути задіяний системний підхід, що передбачає збалансування та послідовність у застосуванні низки механізмів та інструментів. Одним із таких інструментів є включення цільових показників діяльності закладу вищої освіти до контракту, що підписується Міністерством освіти і науки України з керівником закладу на період його каденції. Парадигмальною основою таких цільових показників у сучасних умовах розвитку вищої освіти слугує концепція ефективного врядування.

Ключові слова: врядування у вищій освіті; ефективне врядування у вищій освіті; ефективність діяльності закладів вищої освіти; цільові показники діяльності.

\section{Вступ}

Пропозиції розроблені фахівцями Інституту вищої освіти Національної академії педагогічних наук України на запит т.в.о. Міністра освіти і науки України С. Шкарлета (лист МОН України від 11 серпня 2020 р. № 1/11-5343).

Пропозиції базуються на аналізі провідного вітчизняного та міжнародного досвіду оцінювання ефективності діяльності закладів вищої освіти.

Пропозиції враховують стратегічні цілі та індикатори їх досягнення, представлені у проєкті Стратегії розвитку вищої освіти на 20212031 роки, розміщеному на сайті Міністерства освіти і науки України для громадського обговорення у вересні 2020 року.

Цільові показники згруповані за основними видами діяльності закладів вищої освіти (далі 3ВО), до яких віднесено такі:

- Освітня діяльність ЗВО.

- Дослідницька діяльність ЗВО.

- Міжнародна діяльність 3ВО.

- Соціальна діяльність $3 В 0$ та вплив на розвиток регіонів.

- Фінансово-економічна діяльність та розвиток інфраструктури ЗВО.

- Ефективне врядування та розвиток кадрового потенціалу ЗВО.

Цільові показники представлені у форматі:

- назва показника;

- механізм перевірки досягнення показника, включаючи критерії оцінювання.

Пропоновані цільові показники діяльності закладу вищої освіти мають відносний характер (вимірюються у \%) або фактичний характер (статус, наявність) та засвідчують позитивну динаміку розвитку закладу вищої освіти у визначений період часу.

За своєю суттю пропоновані показники є якісними та результат-орієнтованими, засвідчуючи системні зміни у діяльності закладу вищої освіти.

\section{Рекомендації щодо обрання показників}

Цільові показники діяльності закладу вищої освіти, що включаються до контракту керівника закладу вищої освіти, обираються на основі наступних принципів:

- академічна свобода та університетська автономія;

- відповідність ключовим пріоритетам розвитку закладу вищої освіти, визначеним у Стратегії розвитку закладу;

- відкритість, партнерство та взаємодія;

- орієнтація на ефективне врядування та розподілене лідерство.

Рекомендується включати до контракту керівника закладу вищої освіти не більше дев'яти цільових показників, що відображають ключові тенденції у розвитку закладу вищої освіти, та здійснювати щорічний моніторинг результатів їх досягнення. Вибір показників має чітко корелюватися зі стратегічними цілями розвитку закладу. Провідний досвід засвідчує відсутність набору показників чи вимог щодо вибору видів діяльності, обов' язкових для всіх ЗВО.

\section{Скорочення, що використовуються}

ЗВО - заклад вищої освіти

ОП - освітня програма

НПП - науково-педагогічні працівники

НПП (ом) - науково-педагогічні працівники, які працюють за основним місцем роботи

НАЗЯВО - Національне агентство із забезпечення якості вищої освіти

Освітня діяльність ЗВО

\begin{tabular}{|l|l|}
\hline \multicolumn{1}{|l}{ Цільовий показник } & \multicolumn{1}{|c|}{$\begin{array}{c}\text { Механізм перевірки } \\
\text { досягнення показника, } \\
\text { включаючи критерії } \\
\text { оцінювання }\end{array}$} \\
\hline $\begin{array}{l}\text { ОП, акредитовані 3 } \\
\text { визначенням } \\
\text { «зразкова» }\end{array}$ & $\begin{array}{l}\text { \% від загальної кількості } \\
\text { ОП, які реалізує 3ВО } \\
\text { Рішення НАЗяВО або } \\
\text { галузевої незалежної } \\
\text { агенції }\end{array}$ \\
\hline $\begin{array}{l}\text { ОП, акредитовані } \\
\text { міжнародними }\end{array}$ & $\begin{array}{l}\text { \% від загальної кількості } \\
\text { ОП, які реалізує ЗВО }\end{array}$ \\
\hline
\end{tabular}


Продовження таблиці 1

\begin{tabular}{|c|c|}
\hline Цільовий показник & $\begin{array}{c}\text { Механізм перевірки } \\
\text { досягнення показника, } \\
\text { включаючи критерії } \\
\text { оцінювання }\end{array}$ \\
\hline організаціями & $\begin{array}{l}\text { Рішення міжнародної / } \\
\text { зарубіжної агенції }\end{array}$ \\
\hline $\begin{array}{l}\text { Якість вступника до } \\
\text { ЗВО }\end{array}$ & $\begin{array}{l}\text { \% зростання середнього } \\
\text { конкурсного балу } \\
\text { вступника до ЗВО } \\
\text { Дані системи Конкурс } \\
\text { (Інфоресурс, Вступ) }\end{array}$ \\
\hline $\begin{array}{l}\text { Якість здобувачів } \\
\text { вищої освіти }\end{array}$ & $\begin{array}{l}\text { \% переможців і призерів } \\
\text { міжнародних олімпіад } \\
\text { (конкурсів) від загальної } \\
\text { кількості здобувачів вищої } \\
\text { освіти ЗВО } \\
\text { Дані, представлені на } \\
\text { сайті ЗВО }\end{array}$ \\
\hline $\begin{array}{l}\text { Працевлаштування } \\
\text { випускників }\end{array}$ & $\begin{array}{l}\text { \% від загальної кількості } \\
\text { випускників } \\
\text { Дані Пенсійного фонду } \\
\text { України (платники ЄСВ) }\end{array}$ \\
\hline
\end{tabular}

Таблиия 2

Дослідницька діяльність ЗВО

\begin{tabular}{|c|c|}
\hline Цільовий показник & $\begin{array}{c}\text { Механізм перевірки } \\
\text { досягнення показника, } \\
\text { включаючи критерії } \\
\text { оцінювання }\end{array}$ \\
\hline $\begin{array}{l}\text { Частка здобувачів } \\
\text { вищої освіти, які } \\
\text { навчаються на } \\
\text { третьому рівні вищої } \\
\text { освіти }\end{array}$ & $\begin{array}{l}\text { \% від загальної кількості } \\
\text { здобувачів вищої освіти } \\
\text { ЗВО } \\
\text { Дані офіційної } \\
\text { статистичної звітності }\end{array}$ \\
\hline $\begin{array}{l}\text { Частка докторантів, } \\
\text { які проходять } \\
\text { підготовку на } \\
\text { науковому рівні } \\
\text { вищої освіти }\end{array}$ & $\begin{array}{l}\text { \% від загальної кількості } \\
\text { здобувачів вищої освіти } \\
\text { ЗВО } \\
\text { Дані офіційної } \\
\text { статистичної звітності }\end{array}$ \\
\hline $\begin{array}{l}\text { Атестація ЗВО як } \\
\text { наукової установи, } \\
\text { група А }\end{array}$ & $\begin{array}{l}\text { Державна атестація } 3 \text { ВО в } \\
\text { частині провадження ним } \\
\text { наукової (науково- } \\
\text { технічної) діяльності } \\
\text { Рішення МОН України }\end{array}$ \\
\hline $\begin{array}{l}\text { Статус } \\
\text { дослідницького } \\
\text { університету }\end{array}$ & $\begin{array}{l}\text { Набуття статусу } \\
\text { Постанова Кабінету } \\
\text { Міністрів України }\end{array}$ \\
\hline $\begin{array}{l}\text { Обсяг коштів на } \\
\text { виконання наукових } \\
\text { досліджень і } \\
\text { розробок }\end{array}$ & $\begin{array}{l}\text { \% від бюджету } 3 \text { ВО та } \\
\text { фактичне значення } \\
\text { показника у розрахунку на } \\
\text { одного НПП }\end{array}$ \\
\hline
\end{tabular}

Продовження таблиці 2

\begin{tabular}{|c|c|}
\hline Цільовий показник & $\begin{array}{c}\text { Механізм перевірки } \\
\text { досягнення показника, } \\
\text { включаючи критерії } \\
\text { оцінювання }\end{array}$ \\
\hline & $\begin{array}{l}\text { Дані офіційної } \\
\text { статистичної звітності }\end{array}$ \\
\hline $\begin{array}{l}\text { Обсяг коштів на } \\
\text { виконання наукових } \\
\text { досліджень і } \\
\text { розробок, які } \\
\text { фінансуються із } \\
\text { загального фонду } \\
\text { бюджету ЗВО }\end{array}$ & $\begin{array}{l}\text { \% від бюджету ЗВО та } \\
\text { фактичне значення } \\
\text { показника у розрахунку на } \\
\text { одного НПП } \\
\text { Дані офіційної } \\
\text { статистичної звітності }\end{array}$ \\
\hline $\begin{array}{l}\text { Обсяг коштів на } \\
\text { виконання наукових } \\
\text { досліджень і } \\
\text { розробок, які } \\
\text { фінансуються зі } \\
\text { спеціального фонду } \\
\text { бюджету ЗВО }\end{array}$ & $\begin{array}{l}\text { \% від бюджету ЗВО та } \\
\text { фактичне значення } \\
\text { показника у розрахунку на } \\
\text { одного НПП } \\
\text { Дані офіційної } \\
\text { статистичної звітності }\end{array}$ \\
\hline $\begin{array}{l}\text { Індекс Гірша НПП } \\
\text { (для ЗВО в цілому) }\end{array}$ & $\begin{array}{l}\text { \% зростання та фактичне } \\
\text { значення } \\
\text { Дані Google Scholar }\end{array}$ \\
\hline $\begin{array}{l}\text { Позиція ЗВО за } \\
\text { даними бази Scopus }\end{array}$ & $\begin{array}{l}\text { \% зростання та фактичне } \\
\text { значення } \\
\text { Підвищення позиції у } \\
\text { Рейтингу закладів вищої } \\
\text { освіти України за даними } \\
\text { наукометричної бази } \\
\text { даних Scopus }\end{array}$ \\
\hline $\begin{array}{l}\text { Наукові публікації } \\
\text { НПП (ом), } \\
\text { опубліковані у } \\
\text { наукових виданнях, } \\
\text { що індексуються у } \\
\text { наукометричних } \\
\text { базах даних Scopus / } \\
\text { Web of Science Core } \\
\text { Collection та входять } \\
\text { до першого або } \\
\text { другого квартилів } \\
\text { (Q1-Q2) }\end{array}$ & $\begin{array}{l}\text { \% від загальної кількості } \\
\text { наукових публікацій НПП } \\
\text { (ом) } \\
\text { Дані, представлені на } \\
\text { сайті ЗВО }\end{array}$ \\
\hline $\begin{array}{l}\text { Наукові періодичні } \\
\text { видання 3ВО, що } \\
\text { належать до } \\
\text { категорії А }\end{array}$ & $\begin{array}{l}\text { \% від загальної кількості } \\
\text { наукових періодичних } \\
\text { видань ЗВО } \\
\text { Перелік наукових фахових } \\
\text { видань України }\end{array}$ \\
\hline
\end{tabular}


Міжнародна діяльність 3ВО

\begin{tabular}{|c|c|}
\hline Цільовий показник & $\begin{array}{c}\text { Механізм перевірки } \\
\text { досягнення показника, } \\
\text { включаючи критерії } \\
\text { оцінювання }\end{array}$ \\
\hline $\begin{array}{l}\text { Приналежність 3ВО } \\
\text { до провідних } \\
\text { міжнародних } \\
\text { університетських } \\
\text { рейтингів }\end{array}$ & $\begin{array}{l}\text { \% зростання та фактичне } \\
\text { значення } \\
\text { Наявність та підвищення } \\
\text { позиції у рейтингах } \\
\text { Academic Ranking of World } \\
\text { Universities, The Times } \\
\text { Higher Education World } \\
\text { University Rankings, QS } \\
\text { World University Rankings, } \\
\text { що визнані Урядом } \\
\text { Дані рейтингів }\end{array}$ \\
\hline $\begin{array}{l}\text { ОП, що } \\
\text { викладаються } \\
\text { англійською мовою }\end{array}$ & $\begin{array}{l}\text { \% від загальної кількості } \\
\text { ОП, які реалізує ЗВО } \\
\text { Дані, представлені на } \\
\text { сайті ЗВО }\end{array}$ \\
\hline $\begin{array}{l}\text { ОП із спільними або } \\
\text { подвійними } \\
\text { дипломами }\end{array}$ & $\begin{array}{l}\text { \% від загальної кількості } \\
\text { ОП, які реалізує ЗВО } \\
\text { Реалізуються спільно з } \\
\text { зарубіжними ЗВО } \\
\text { Дані, представлені на } \\
\text { сайті ЗВО }\end{array}$ \\
\hline $\begin{array}{l}\text { Іноземні здобувачі } \\
\text { вищої освіти денної } \\
\text { форми здобуття } \\
\text { вищої освіти }\end{array}$ & $\begin{array}{l}\text { \% від загальної кількості } \\
\text { здобувачів вищої освіти } \\
\text { ЗВО денної форми } \\
\text { здобуття вищої освіти } \\
\text { Дані офіційної } \\
\text { статистичної звітності }\end{array}$ \\
\hline $\begin{array}{l}\text { Іноземні здобувачі } \\
\text { вищої освіти денної } \\
\text { форми здобуття } \\
\text { вищої освіти з } \\
\text { країн - членів } \\
\text { Організації } \\
\text { економічного } \\
\text { співробітництва і } \\
\text { розвитку }\end{array}$ & $\begin{array}{l}\text { \% від загальної кількості } \\
\text { здобувачі вищої освіти } \\
\text { ЗВО денної форми } \\
\text { здобуття вищої освіти } \\
\text { Дані офіційної } \\
\text { статистичної звітності }\end{array}$ \\
\hline $\begin{array}{l}\text { Частка НПП- } \\
\text { іноземців }\end{array}$ & $\begin{array}{l}\text { \% від загальної кількості } \\
\text { НПП ЗВО } \\
\text { Дані офіційної } \\
\text { статистичної звітності }\end{array}$ \\
\hline $\begin{array}{l}\text { Обсяг коштів } \\
\text { (включаючи вартість } \\
\text { обладнання), що } \\
\text { надходять ЗВО за } \\
\text { міжнародними } \\
\text { проєктами }\end{array}$ & $\begin{array}{l}\text { \% від бюджету ЗВО } \\
\text { Дані офіційної } \\
\text { статистичної звітності }\end{array}$ \\
\hline
\end{tabular}

\begin{tabular}{|c|c|}
\hline Цільовий показник & $\begin{array}{c}\text { Механізм перевірки } \\
\text { досягнення показника, } \\
\text { включаючи критерії } \\
\text { оцінювання }\end{array}$ \\
\hline $\begin{array}{l}\text { Міжнародна } \\
\text { мобільність } \\
\text { здобувачів вищої } \\
\text { освіти }\end{array}$ & $\begin{array}{l}\text { \% від загальної кількості } \\
\text { здобувачі вищої освіти } \\
\text { ЗВО денної форми } \\
\text { здобуття вищої освіти } \\
\text { Академічна мобільність } \\
\text { від } 1 \text { місяця } \\
\text { Дані, представлені на } \\
\text { сайті ЗВО }\end{array}$ \\
\hline $\begin{array}{l}\text { Міжнародна } \\
\text { мобільність НПП } \\
\text { (ом) }\end{array}$ & $\begin{array}{l}\text { \% від загальної кількості } \\
\text { НПП (ом) } \\
\text { Академічна мобільність } \\
\text { від } 1 \text { тижня } \\
\text { Дані, представлені на } \\
\text { сайті ЗВО }\end{array}$ \\
\hline $\begin{array}{l}\text { Наукові публікації } \\
\text { НПП (ом), які } \\
\text { опубліковані у } \\
\text { зарубіжних наукових } \\
\text { виданнях }\end{array}$ & $\begin{array}{l}\text { \% від загальної кількості } \\
\text { наукових публікацій НПП } \\
\text { (ом) } \\
\text { Дані, представлені на } \\
\text { сайті ЗВО }\end{array}$ \\
\hline $\begin{array}{l}\text { Наукові публікації } \\
\text { НПП (ом) із } \\
\text { зарубіжними } \\
\text { співавторами, які } \\
\text { опубліковані у } \\
\text { вітчизняних } \\
\text { наукових виданнях }\end{array}$ & $\begin{array}{l}\text { \% від загальної кількості } \\
\text { наукових публікацій НПП } \\
\text { (ом) } \\
\text { Дані, представлені на } \\
\text { сайті ЗВО }\end{array}$ \\
\hline
\end{tabular}

Табличя 4

Соціальна діяльність ЗВО та вплив на розвиток регіонів

\begin{tabular}{|l|l|}
\hline \multicolumn{1}{|l|}{ Цільовий показник } & \multicolumn{1}{|c|}{$\begin{array}{c}\text { Механізм перевірки } \\
\text { досягнення показника, } \\
\text { включаючи критерії } \\
\text { оцінювання }\end{array}$} \\
\hline $\begin{array}{l}\text { Обсяг коштів, що } \\
\text { надходять 3ВО з } \\
\text { місцевого бюджету } \\
\text { для реалізації } \\
\text { регіональних } \\
\text { проєктів }\end{array}$ & $\begin{array}{l}\text { \% від бюджету 3ВО та } \\
\text { фактичне значення } \\
\text { показника у розрахунку на } \\
\text { одного НПП } \\
\text { Дані офіційної } \\
\text { статистичної звітності }\end{array}$ \\
\hline $\begin{array}{l}\text { Обсяг коштів, що } \\
\text { надходять 3ВО від } \\
\text { регіональних } \\
\text { організацій та } \\
\text { підприємств }\end{array}$ & $\begin{array}{l}\text { \% від загального бюджету } \\
\text { ЗВО та фактичне значення } \\
\text { показника у розрахунку на } \\
\text { одного НПП } \\
\text { Дані офіційної } \\
\text { статистичної звітності }\end{array}$ \\
\hline
\end{tabular}


Продовження таблищі 4

\begin{tabular}{|c|c|}
\hline Цільовий показник & $\begin{array}{c}\text { Механізм перевірки } \\
\text { досягнення показника, } \\
\text { включаючи критерії } \\
\text { оцінювання }\end{array}$ \\
\hline $\begin{array}{l}\text { Обсяг коштів, що } \\
\text { надходять ЗВО з } \\
\text { місцевого бюджету } \\
\text { як регіональне } \\
\text { замовлення на } \\
\text { підготовку фахівців }\end{array}$ & $\begin{array}{l}\text { \% від бюджету ЗВО та } \\
\text { фактичне значення } \\
\text { показника у розрахунку на } \\
\text { одного НПП } \\
\text { Дані офіційної } \\
\text { статистичної звітності }\end{array}$ \\
\hline $\begin{array}{l}\text { ОП, які реалізуються } \\
\text { за дуальною } \\
\text { формою здобуття } \\
\text { вищої освіти спільно } \\
\text { з підприємствами } \\
\text { регіону }\end{array}$ & $\begin{array}{l}\text { \% від загальної кількості } \\
\text { ОП ЗВО } \\
\text { Дані, представлені на } \\
\text { сайті ЗВО }\end{array}$ \\
\hline $\begin{array}{l}\text { Частка здобувачів } \\
\text { вищої освіти, які } \\
\text { навчаються за ОП за } \\
\text { спеціальностями, } \\
\text { визначеними } \\
\text { Урядом як } \\
\text { пріоритетні }\end{array}$ & $\begin{array}{l}\text { \% від загальної кількості } \\
\text { здобувачів вищої освіти } \\
\text { ЗВО та фактичний } \\
\text { показник середнього } \\
\text { конкурсного балу } \\
\text { вступників } \\
\text { Дані офіційної } \\
\text { статистичної звітності та } \\
\text { системи Конкурс } \\
\text { (Інфоресурс, Вступ) }\end{array}$ \\
\hline $\begin{array}{l}\text { Частка здобувачів } \\
\text { вищої освіти } 3 \\
\text { особливими } \\
\text { освітніми потребами }\end{array}$ & $\begin{array}{l}\text { \% від загальної кількості } \\
\text { здобувачів вищої освіти } \\
\text { ЗВО } \\
\text { Дані офіційної } \\
\text { статистичної звітності }\end{array}$ \\
\hline $\begin{array}{l}\text { Працевлаштовані } \\
\text { випускники у регіоні }\end{array}$ & $\begin{array}{l}\text { \% від загальної кількості } \\
\text { випускників } \\
\text { Дані Пенсійного фонду } \\
\text { України (платники ЄСВ) }\end{array}$ \\
\hline
\end{tabular}

Таблиця 5

Фінансово-економічна діяльність та розвиток інфраструктури ЗВО

\begin{tabular}{|l|l|}
\hline \multicolumn{1}{|c|}{ Цільовий показник } & \multicolumn{1}{|c|}{$\begin{array}{c}\text { Механізм перевірки } \\
\text { досягнення показника, } \\
\text { включаючи критерії } \\
\text { оцінювання }\end{array}$} \\
\hline $\begin{array}{l}\text { Спеціальний фонд } \\
\text { фінансування 3ВО }\end{array}$ & $\begin{array}{l}\text { \% від бюджету 3ВО } \\
\text { Дані офіційної } \\
\text { статистичної звітності }\end{array}$ \\
\hline $\begin{array}{l}\text { Обсяг коштів, що } \\
\text { надходять 3ВО з } \\
\text { державного } \\
\text { бюджету }\end{array}$ & $\begin{array}{l}\text { \% зростання } \\
\text { Дані офіційної } \\
\text { статистичної звітності }\end{array}$ \\
\hline
\end{tabular}

Продовження таблиці 5

\begin{tabular}{|c|c|}
\hline Цільовий показник & $\begin{array}{c}\text { Механізм перевірки } \\
\text { досягнення показника, } \\
\text { включаючи критерії } \\
\text { оцінювання }\end{array}$ \\
\hline $\begin{array}{l}\text { Обсяг коштів } \\
\text { (включаючи вартість } \\
\text { обладнання), що } \\
\text { надходять ЗВО від } \\
\text { юридичних осіб }\end{array}$ & $\begin{array}{l}\text { \% від бюджету 3ВО, окрім } \\
\text { коштів державного } \\
\text { бюджету } \\
\text { Дані офіційної } \\
\text { статистичної звітності }\end{array}$ \\
\hline $\begin{array}{l}\text { Розмір (кошти та } \\
\text { вартість майна) } \\
\text { ендавменту }\end{array}$ & $\begin{array}{l}\text { \% зростання та \% від } \\
\text { бюджету ЗВО } \\
\text { Дані, представлені на } \\
\text { сайті ЗВО }\end{array}$ \\
\hline $\begin{array}{l}\text { Обсяг коштів, } \\
\text { спрямований на } \\
\text { розвиток } \\
\text { інфраструктури ЗВО }\end{array}$ & $\begin{array}{l}\text { \% зростання та \% від } \\
\text { бюджету ЗВО } \\
\text { Дані, представлені на } \\
\text { сайті ЗВО }\end{array}$ \\
\hline $\begin{array}{l}\text { Загальна площа } \\
\text { навчально- } \\
\text { лабораторних } \\
\text { приміщень на правах } \\
\text { власності або } \\
\text { оперативного } \\
\text { управління }\end{array}$ & $\begin{array}{l}\text { \% зростання у розрахунку } \\
\text { на одного здобувача } \\
\text { вищої освіти } \\
\text { Дані, представлені на } \\
\text { сайті ЗВО }\end{array}$ \\
\hline
\end{tabular}

Табличя 6

Ефективне врядування та розвиток кадрового потенціалу ЗВО

\begin{tabular}{|c|c|}
\hline Цільовий показник & $\begin{array}{c}\text { Механізм перевірки } \\
\text { досягнення показника, } \\
\text { включаючи критерії } \\
\text { оцінювання }\end{array}$ \\
\hline $\begin{array}{l}\text { НПП, які працюють у } \\
\text { ЗВО за основним } \\
\text { місцем роботи }\end{array}$ & $\begin{array}{l}\text { \% від загальної кількості } \\
\text { НПП та \% зростання } \\
\text { Дані офіційної } \\
\text { статистичної звітності }\end{array}$ \\
\hline $\begin{array}{l}\text { НПП, які працюють у } \\
\text { ЗВО за основним } \\
\text { місцем роботи та } \\
\text { мають науковий } \\
\text { ступінь / ступінь } \\
\text { доктора мистецтва } \\
\text { та / або вчене } \\
\text { (почесне для } \\
\text { мистецьких ЗВО) } \\
\text { звання }\end{array}$ & $\begin{array}{l}\text { \% від загальної кількості } \\
\text { НПП та \% зростання } \\
\text { Дані офіційної } \\
\text { статистичної звітності }\end{array}$ \\
\hline $\begin{array}{l}\text { Співвідношення } \\
\text { кількості НПП (ом) з } \\
\text { науковим ступенем / } \\
\text { ступенем доктора } \\
\text { мистецтва та / або } \\
\text { вченим (почесне для }\end{array}$ & $\begin{array}{l}\text { \% зростання } \\
\text { Дані офіційної } \\
\text { статистичної звітності }\end{array}$ \\
\hline
\end{tabular}


Продовження таблищі 6

\begin{tabular}{|c|c|}
\hline Цільовий показник & $\begin{array}{c}\text { Механізм перевірки } \\
\text { досягнення показника, } \\
\text { включаючи критерії } \\
\text { оцінювання }\end{array}$ \\
\hline $\begin{array}{l}\text { мистецьких 3ВО) } \\
\text { званням до кількості } \\
\text { здобувачів вищої } \\
\text { освіти }\end{array}$ & \\
\hline $\begin{array}{l}\text { Обсяг коштів, } \\
\text { спрямованих на } \\
\text { підвищення } \\
\text { кваліфікації НПП }\end{array}$ & $\begin{array}{l}\text { \% зростання та фактичний } \\
\text { показник на одного НПП } \\
\text { Дані офіційної } \\
\text { статистичної звітності }\end{array}$ \\
\hline $\begin{array}{l}\text { Зв'язок з } \\
\text { роботодавцями }\end{array}$ & $\begin{array}{l}\text { \% здобувачів вищої освіти, } \\
\text { які проходять практику на } \\
\text { підприємствах поза ЗВО, } \\
\text { від загальної кількості } \\
\text { здобувачів вищої освіти та } \\
\text { \% зростання }\end{array}$ \\
\hline
\end{tabular}

\section{СПИСОК ВИКОРИСТАНИХ ДЖЕРЕЛ}

Закон України «Про вищу освіту». (2014, 1 липня). Cтаття 30. Дослідницький університет. https:// zakon.rada.gov.ua/laws/show/1556-18

Кабінет Міністрів України. (2017, 22 листопада). Про затвердження Порядку та критеріїв надання закладу вищої освіти статусу національного, підтвердження чи позбавлення цього статусу (912). https://zakon.rada.gov.ua/laws/show/912-2017-п

Кабінет Міністрів України. (2018, 14 квітня). Про затвердження переліку світових рейтингів університетів для визначення особливої категорії іноземців та осіб без громадянства, які претендують на працевлаштування в Україні (154-p). https:// zakon.rada.gov.ua/laws/show/154-2018-p

Кабінет Міністрів України. (2019, 24 грудня). Про розподіл державного бюджету між закладами вищої освіти на основі показників їх освітньої, наукової ma міжнародної діяльності (1146). https:// zakon.rada.gov.ua/laws/show/1146-2019-п

Кабінет Міністрів України. (2020, 13 травня). Про внесення змін до типової форми контракту з керівником державного закладу вищої освіти (360). https://zakon.rada.gov.ua/laws/show/360-2020-п

Міністерство освіти і науки України. (2019, 12 березня). Про державну атестацію закладів вищої освіти в частині провадження ними наукової (науково-технічної) діяльності (338). https:// zakon.rada.gov.ua/laws/show/z0688-19

Міністерство освіти і науки України. (2020, 25 вересня). МОН пропонує для громадського обговорення проєкт Cтратегії розвитку вищої освіти України. https://mon.gov.ua/ua/news/mon-proponuye-dlyagromadskogo-obgovorennya-proyekt-strategiyirozvitku-vishoyi-osviti-ukrayini

Національне агентство із забезпечення якості вищої освіти. (2019). Виконання критеріїв надання та підтвердження статусу національного закладу вищої освіти : Аналітичний звіт. https://naqa.gov.ua/ wp-content/uploads/2019/10/A-2019-1-20191015-3.pdf

\section{ORIENTATION OF THE UNIVERSITY LEADER ON THE INSTITUTION'S EFFICIENT DEVELOPMENT \\ Proposals of the Institute of Higher Education of the National Academy of Educational Sciences of Ukraine for the higher education institution's Key Performance Indicators (KPIs), which are included to the contact with the institution's leader}

Iryna Drach

DSc in Education, Associate Professor, First Deputy Director, Institute of Higher Education of the National Academy of Educational Sciences of Ukraine, Kyiv, Ukraine Svitlana Kalashnikova

DSc in Education, Professor, Corresponding Member of NAES of Ukraine, Director, Institute of Higher Education of the National Academy of Educational Sciences of Ukraine, Member of the National Higher Education Reform Experts Team, Kyiv, Ukraine Volodymyr Lugovyi

DSC in Education, Professor, Full Member (Academician) of NAES of Ukraine, First Vice-President, National Academy of Educational Sciences of Ukraine, Member of the National Higher Education Reform Experts Team, Kyiv, Ukraine Olena Sliusarenko

DSc in Education, Senior Researcher, Deputy Director for Research Work, Institute of Higher Education of the National Academy of Educational Sciences of Ukraine, Kyiv, Ukraine Zhanna Talanova

DSc in Education, Senior Researcher, Associate Professor, Chief Research Fellow of the Department for Policy and Governance in Higher Education, Institute of Higher Education of the National Academy of Educational Sciences of Ukraine, Analytical Manager, National Erasmus+ Office in Ukraine, Kyiv, Ukraine

Abstract: Increasing the higher education institutions' efficiency is one of the key tasks on the agenda of higher education reform in Ukraine. The system approach should be used for its fulfillment; the approach presupposes balancing and consistency in the application of a number of mechanisms and tools. One such tool is to include the higher education institution Key Performance Indicators (KPIs) to the contact between the Ministry of Education and Science of Ukraine and the institution's leader. Under the modern conditions of higher education development, the concept of efficient governance serves as the paradigm basis for the key indicators.

Keywords: governance in higher education; efficient governance in higher education; higher education institutions performance efficiency; Key Performance Indicators (KPIs).

Дата публікації: 20 листопада 2020 р. 